in vivo $33: 707-715(2019)$

doi:10.21873/invivo.11529

\title{
Inhibitory Effect of Olive Leaf Extract on Obesity in High-fat Diet-induced Mice
}

\author{
YUN-CHAN JUNG ${ }^{1 *}$, HYUN WOO KIM ${ }^{1 *}$, BOK KEE MIN ${ }^{2}$, JAE YOUNG CHO ${ }^{2}$, HYO JEONG SON ${ }^{2}$, \\ JA YOUNG LEE ${ }^{2}$, JI-YOUNG KIM ${ }^{2}$, SAE-BOM KWON ${ }^{2}$, QIANG LI ${ }^{1}$ and HEE-WOO LEE ${ }^{1}$ \\ ${ }^{1}$ Institute of Research and Development, Chaon Corp., Seongnam, Republic of Korea; \\ ${ }^{2}$ Nova K Health Corp., Seoul, Republic of Korea
}

\begin{abstract}
Background/Aim: The rapid increase in the number of people who are overweight or obese, which increases the risk of diseases and health problems, is becoming an important issue. Herein, we investigated whether olive leaf extract (OLE) has potent anti-obesity effects in high-fat induced mouse models. Materials and Methods: C57BL/6 mice were randomized into normal control, high-fat diet (HFD), HFD with OLE, and HFD with garcinia groups and administered experimental diets for 12 weeks. Body weight and food intake were measured once per week and obesity-related biomarkers were evaluated in the serum and adipose tissue. Results: OLE significantly suppressed weight gain, food efficiency ratio, visceral fat accumulation, and serum lipid composition in HFD-induced mice. Furthermore, the expression of adipogenesis- and thermogenesis-related molecules was decreased in the OLE-treated group. Conclusion: OLE prevents obesity development by regulating the expression of molecules involved in adipogenesis and thermogenesis.
\end{abstract}

Obesity is a complex disorder involving an excessive amount of body fat resulting from the accumulation of white adipose tissue (1). The number of people who are overweight or obese is rapidly increasing, creating an important health issue by increasing the risk of diseases and health problems such as

This article is freely accessible online.

*These Authors contributed equally to this study.

Correspondence to: Qiang $\mathrm{Li}$, Institute of Research and Development, Chaon Corp., 230 Pangyoyeok-ro, Bundang-gu, Seongnam-si, Gyeonggi-do 13493, Republic of Korea. Tel/Fax: +82 316984780/+82 316984784, e-mail: liqiang8589@snu.ac.kr; HeeWoo Lee, Institute of Research and Development, Chaon Corp., 230 Pangyoyeok-ro, Bundang-gu, Seongnam-si, Gyeonggi-do 13493, Republic of Korea. Tel/Fax: +82 316984780/+82 316984784, e-mail: dinks90@chaon.kr

Key Words: Obesity, olive leaf extract, fat, adipogenesis, thermogenesis. cardiovascular diseases, type 2 diabetes, obstructive sleep apnea, certain types of cancer, osteoarthritis, hypertension, hyperlipidemia, and depression (2-4). Obesity typically results from a combination of causes and contributing factors, including genetics, family lifestyle, inactivity, unhealthy diet, age, pregnancy, social determinants, and medical problems such as Prader-Willi syndrome, Cushing's syndrome, and other conditions. It is characterized by an increase in adipocyte cell size and number, leading to an abnormal increase in fat mass and excessive fat accumulation in various organs. Adipogenesis is the process by which adipocytes differentiate from the mesenchymal lineage and is regulated by the Wnt/ $\beta$-catenin signaling pathway $(1,5)$. This differentiation is controlled by the activities of several important transcription factors, such as peroxisome proliferator-activated receptor- $\gamma$ (PPAR- $\gamma$ ) and members of the CCAAT/enhancer-binding protein family (6-9). These factors play important roles in adipogenesis and lipogenesis, and studies of their signaling pathways have improved the understanding of adipogenesis mechanisms. Additionally, obesity results from a positive energy balance that occurs when energy intake exceeds expenditure. Thermogenesis increases energy expenditure in mitochondria-rich brown adipocytes in brown fat tissue and is triggered by intracellular mechanisms in response to exercise, diet, or cold exposure (10-14). Regulators of thermogenesis, such as peroxisome proliferator-activated receptor $\gamma$ coactivator-1alpha (PGC- $1 \alpha$ ), interferon regulatory factor 4 , and PR-domain containing 16 regulate the expression of genes encoding uncoupling protein 1 (UCP1) (15-17), which depolarizes the inner mitochondrial membrane to cause proton transfer and heat dissipation. Therefore, screening for therapeutic agents that control the expression of key regulators of adipogenesis and thermogenesis is important for preventing obesity.

Olive leaf extract (OLE) is widely consumed in the human diet and has various health benefits. OLE contains some polyphenols in common with olive fruit and oil and has been shown to prevent hypertension, atherosclerosis, cancer, diabetes, and cardiovascular diseases (18-23). In this study, 
we investigated the in vivo preventive effects of OLE on obesity in high-fat diet-fed mice by evaluating the expression of molecules involved in adipogenesis and thermogenesis.

\section{Materials and Methods}

Materials. OLE was provided by Nova K health (Seoul, Korea). The compound was stored at $4^{\circ} \mathrm{C}$ and suspended in sterile phosphatebuffer saline (Invitrogen, Carlsbad, CA, USA). Garcinia extract was provided by Nova $\mathrm{K}$ health and administered to mice in the positive control group.

Animals. Five-week-old male C57BL/6 mice weighing 18-21 g were purchased from Orient Bio (Gyeonggi-do, Korea). All mice were housed in a specific pathogen-free standard room under controlled temperature $\left(21.5-22.3^{\circ} \mathrm{C}\right)$, humidity $(47-53.1 \%)$, and light cycle (12:12 h light-dark) conditions; the mice had access to rodent chow and tap water ad libitum for 1 week.

Experimental design. The mice were randomized into the following groups ( $\mathrm{n}=9$ in each group): normal control group (NC), high-fat diet (HFD) group, HFD with OLE $(150 \mathrm{mg} / \mathrm{kg}$ ) administered group, and HFD with garcinia $(200 \mathrm{mg} / \mathrm{kg}$ ) administered group. Mice were fed the experimental diets for 12 weeks. The body weight and food intake of mice were measured once per week. The mice were sacrificed by cardiac puncture under anesthetization and their blood and adipose tissues were collected for further analysis. The serum was isolated from the blood samples by centrifugation at $200 \times g$ for $10 \mathrm{~min}$ and immediately stored at $-80^{\circ} \mathrm{C}$. The adipose tissue (epididymal fat, perirenal, retroperitoneal fat, and mesenteric fat) from each mouse was harvested and weighted. All experimental procedures involving animals were approved by the institutional Animal Care and Use Committee of CHA University (IACUC180078), and the experiments were performed according to the guidelines for animal experiments.

Histological examination. The epididymal fat was rinsed and fixed in $10 \%$ neutral-buffered formalin, embedded in paraffin, and cut into 4- $\mu \mathrm{m}$ sections that were stained with hematoxylin and eosin and observed under a microscope at $100 \times$ magnification. To measure adipocyte diameter, 10 random fields per group were evaluated with Image J software (NIH, Bethesda, MD, USA).

Biochemical analysis. Serum concentrations of total cholesterol (TC), triglyceride (TG), high-density lipoprotein (HDL) cholesterol, free fatty acid (FFA), and glucose were evaluated with commercial assay kits and using the automatic analyzer TBA-30FR Accute (Toshiba, Tokyo, Japan). The levels of LDL+VLDL cholesterol were calculated by subtracting the HDL cholesterol levels from the total cholesterol levels. A small amount of blood was collected from the tail vein, and leptin and adiponectin levels were evaluated at 4 , 8, and 12 weeks using the Mouse/Rat Leptin ELISA Kit (Morinaga, Yokohama, Japan) and Adiponectin ELISA kit (FineTest, Wuhan, China), respectively.

Reverse transcription-polymerase chain reaction (RT-PCR) analysis. Total RNA was extracted from the homogenized adipose tissue using an Easy-BLUE Total RNA Extraction kit (Intron Biotechnology, Seongnam, Republic of Korea) according to the manufacturer's instructions. cDNA was synthesized from $1 \mu \mathrm{g}$ of
Table I. Primer sequences for RT-PCR amplification of target genes.

\begin{tabular}{lll}
\hline Gene & & Primer sets \\
\hline$P P A R \gamma$ & $\mathrm{F}$ & 5'-TTCGGAATCAGCTCTGTGGA-3' \\
& $\mathrm{R}$ & 5'-CCATTGGGTCAGCTCTTGTG-3' \\
$C / E B P-\alpha$ & $\mathrm{F}$ & 5'-AAGGCCAAGAAGTCGGTAGA-3' \\
& $\mathrm{R}$ & 5'-CCATAGTGGAAGCCTGATGC-3' \\
$U C P 1$ & $\mathrm{~F}$ & 5'-GGTTTTGCACCACACTCCTG-3' \\
& $\mathrm{R}$ & 5'-ACATGGACATCGCACAGCTT-3' \\
$P G C-1 \alpha$ & $\mathrm{F}$ & 5'-TAAATCTGCGGGATGATGGA-3' \\
& $\mathrm{R}$ & 5'-GTTTCGTTCGACCTGCGTAA-3' \\
GAPDH & $\mathrm{F}$ & 5'-AGAACATCATCCCTGCATCC-3' \\
& $\mathrm{R}$ & 5'-TCCACCACCCTGTTGCTGTA-3' \\
\hline
\end{tabular}

F: Forward primer; R: reverse primer.

total RNA with CellScript All-in-One cDNA Master Mix (CellSafe, Yongin, Republic of Korea), and the samples were analyzed in triplicate with HiPi PCR Premix (Elpisbio, Daejeon, Republic of Korea). The expression of target genes was normalized to that of glyceraldehyde-3-phosphate dehydrogenase (GAPDH). The primer sequences used in this study are listed in Table I.

Statistical analysis. Data are shown as the mean \pm standard error of the mean (SEM). Differences between groups were compared by one-way or two-way analysis of variance followed by Bonferroni post hoc test with GraphPad Prism v.6.01 software (GraphPad, Inc., La Jolla, CA, USA). $p<0.05$ was considered as statistically significant.

\section{Results}

Effect of OLE on weight gain, food intake, and food efficiency ratio (FER) in HFD-fed mice. After 12 weeks of feeding of the different diets, the HFD group showed a significantly increased final body weight and cumulative weight gain compared to the NC group (Figure 1). A decrease in body weight and weight gain was observed in the OLE group (Figure 1B, C). Food intake levels of the HFD, OLE, and garcinia groups were approximately equal, while the FER was significantly attenuated by OLE and garcinia treatment (Figure 1D, E). Lower body weight and FER were observed in the OLE group compared to the garcinia group.

Effect of OLE on fat accumulation in HFD diet-fed mice. In both the OLE and garcinia groups, the epididymal and retroperitoneal tissue weights were significantly decreased compared to those in the HFD group, with similar changes observed in the total visceral fat weight (Figure 2A). Moreover, histological sections from the epididymal adipose tissue of the HFD group revealed a greater adipocyte diameter compared to that in the NC group; this change in adipocyte size was significantly reversed by OLE and garcinia administration (Figure 2B). 

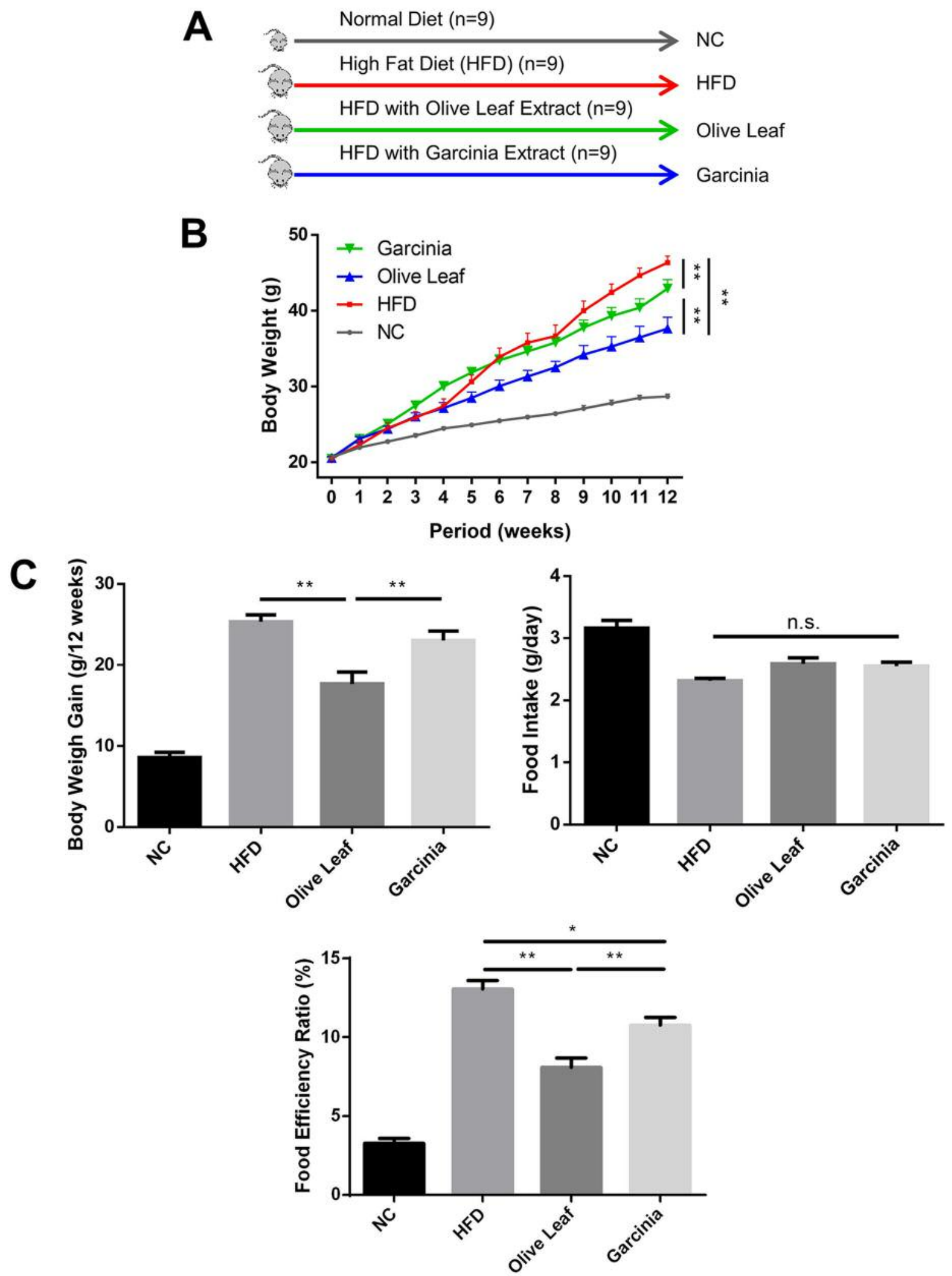

Figure 1. Effects of olive leaf extract on body weight gain, food intake, and food efficiency ratio (FER) of mice fed high-fat diet (HFD). (A) Experimental groups. (B) Body weight change over a 12-week period. (C-E) Body weight gain, food intake, and FER at 12 weeks. Results are presented as the mean $\pm \operatorname{SEM}(n=9)\left({ }^{*} p<0.05,{ }^{*} p<0.01\right.$, N.S.: Not significant, FER=body weight gain for experimental period/food intake for experimental period $)$. 

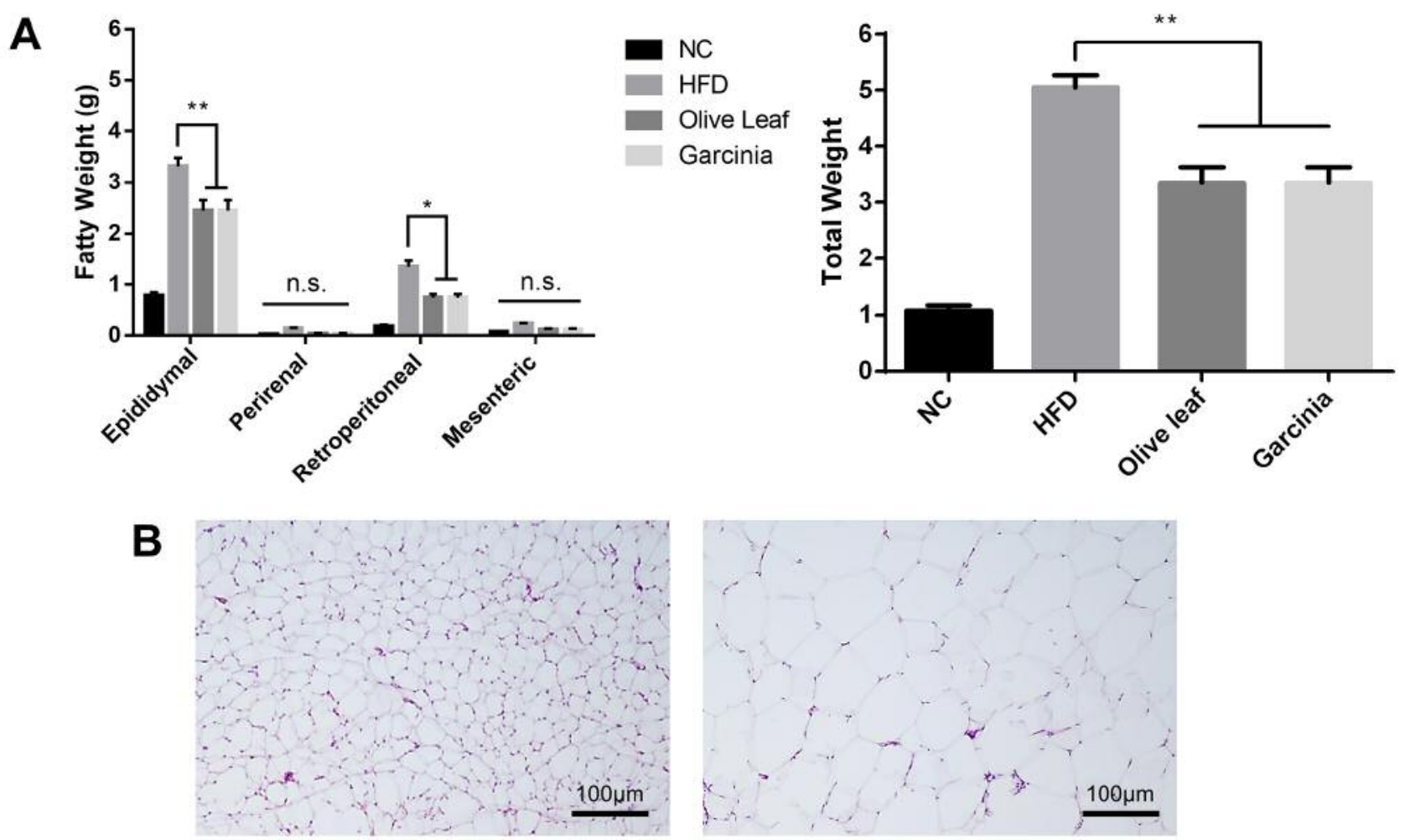

\section{NC}
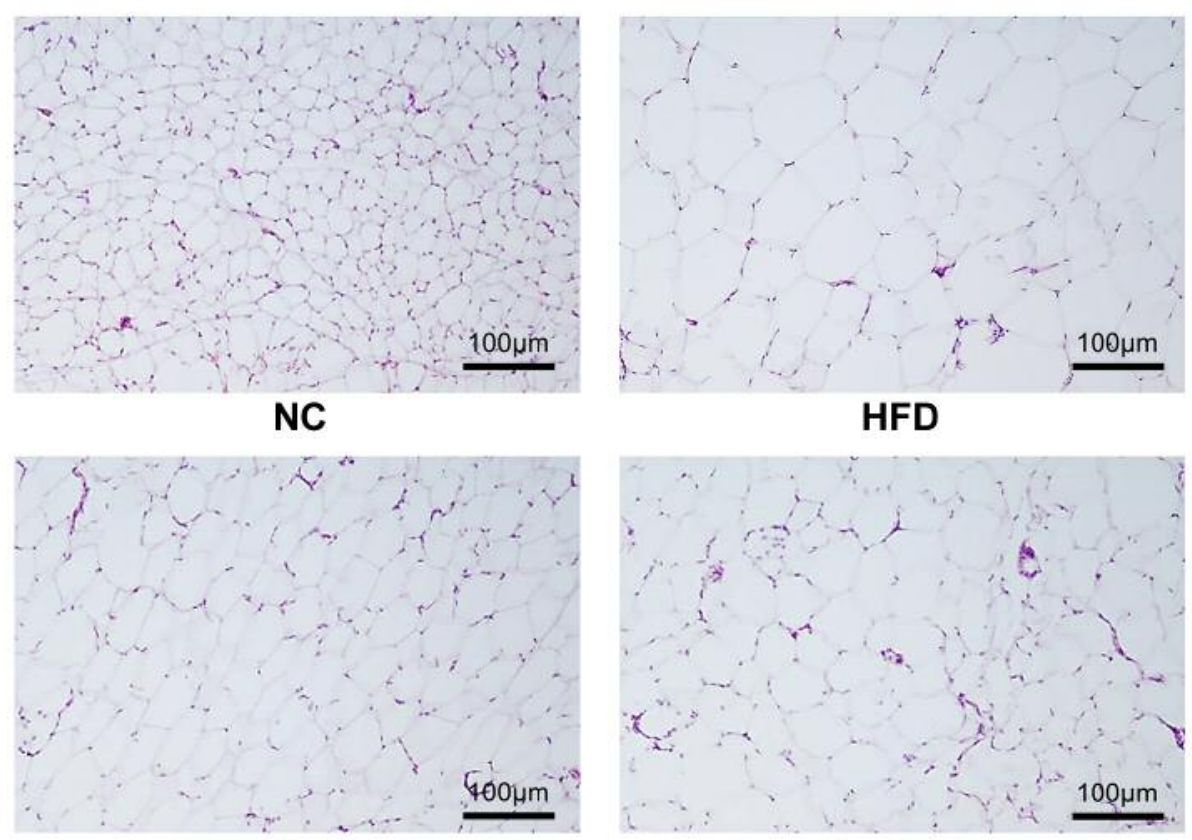

Olive leaf

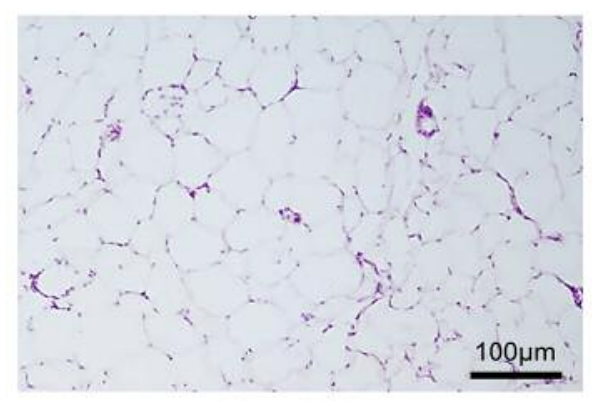

Garcinia

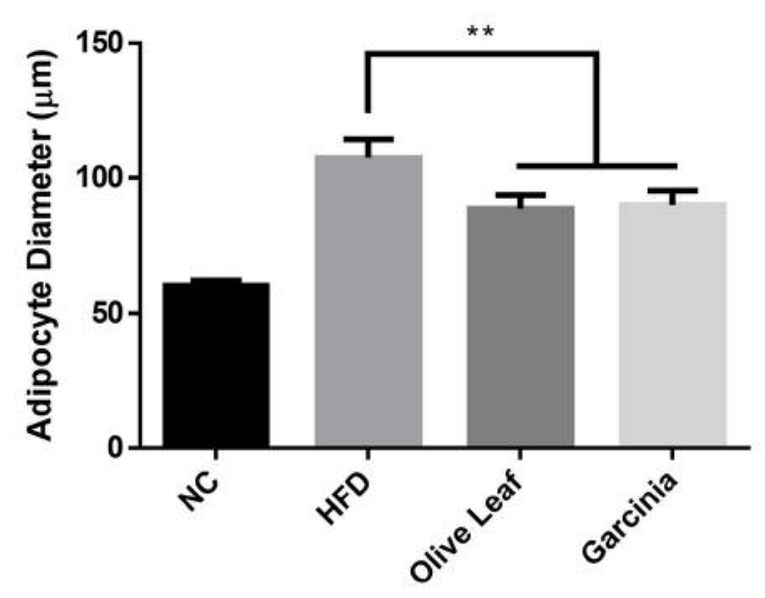

Figure 2. Effect of olive leaf extract on adipose tissue in HFD-induced mice. (A) Fatty weight of epididymal, perirenal, retroperitoneal, mesenteric, and total weight in each experimental group. (B) Histological analysis of the epididymal adipose tissue from each group was conducted to quantify the size of adipocytes. Results are presented as the mean $\pm \operatorname{SEM}(n=9)\left({ }^{*} p<0.05,{ }^{*} p<0.01\right.$, N.S.: Not significant). 

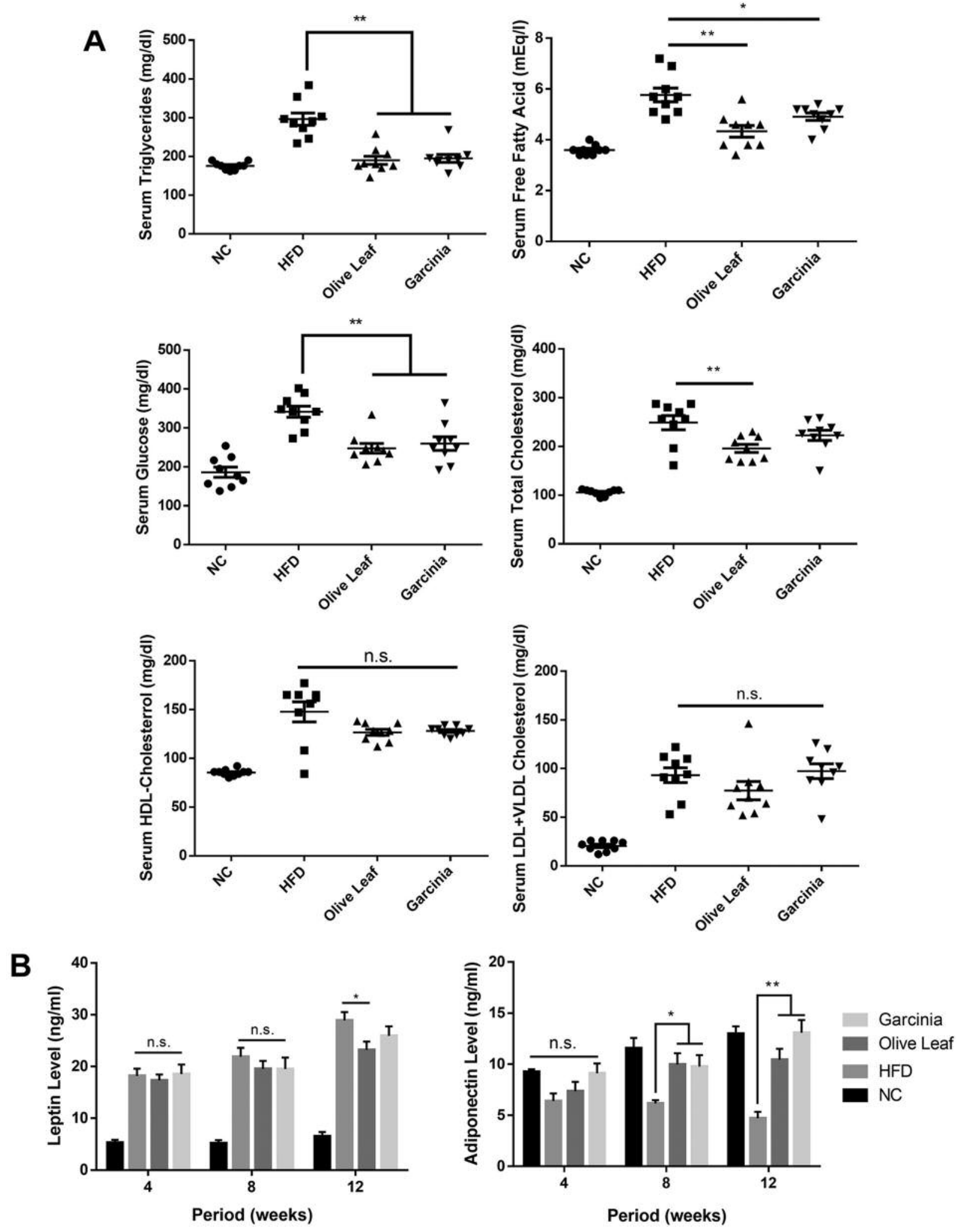

Figure 3. Effects of olive leaf extract on the levels of serum biochemicals and cytokines in obese mice fed high-fat diet. (A) Serum levels of triglycerides, free fatty acid, glucose, total cholesterol, HDL-cholesterol, LDL+VLDL-cholesterol were measured. (B) Leptin and adiponectin levels were analyzed by ELISA. Results are presented as the mean $\pm \operatorname{SEM}(n=9)(* p<0.05, * * p<0.01$, N.S.: Not significant). 

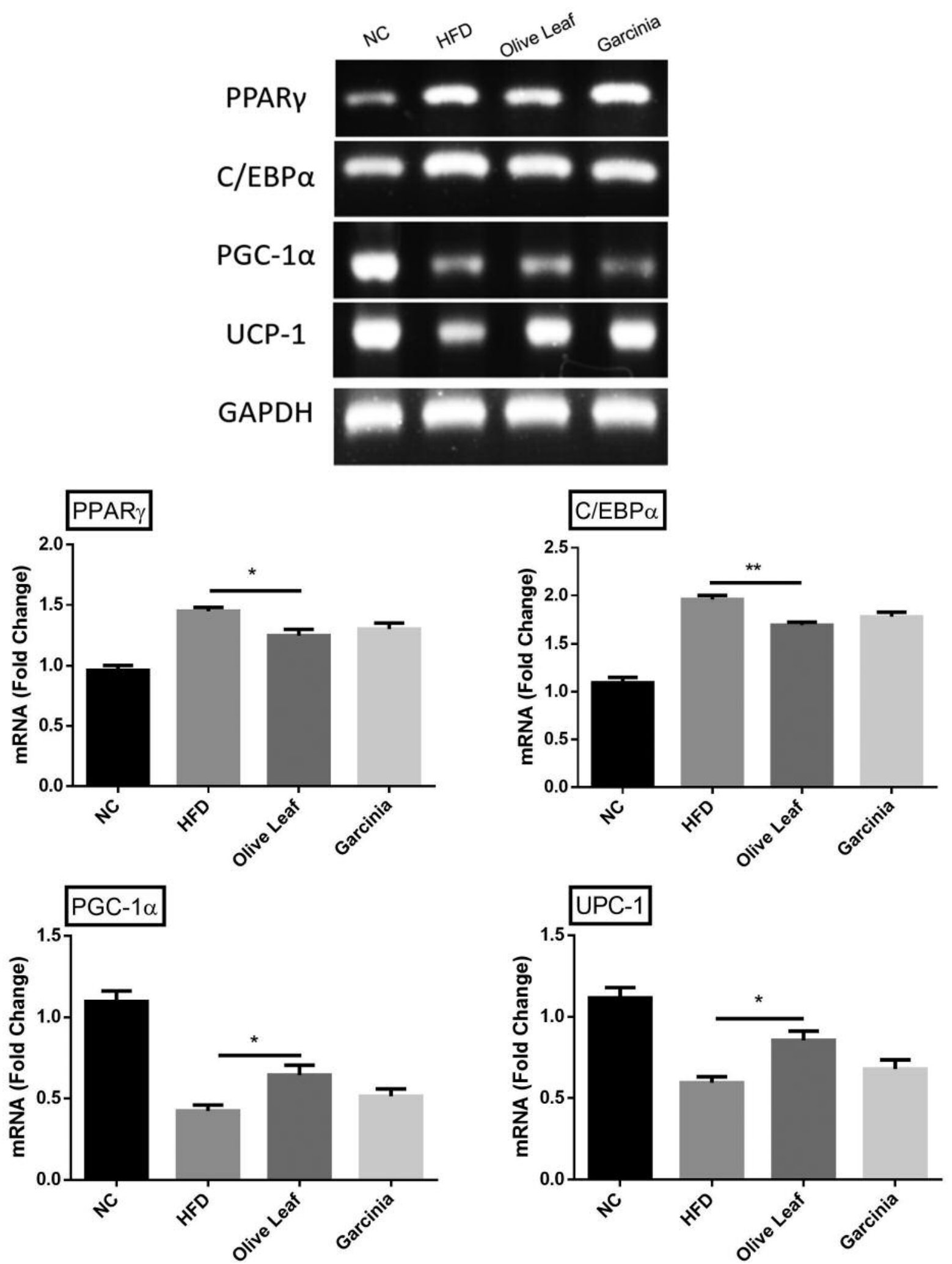

Figure 4. RT-PCR analysis of gene expression in the epididymal adipose tissue. The expression levels of adipogenesis-related (PPAR, C/EBP) and thermogenesis-related (PGC-1, UPC-1) mRNAs were evaluated by RT-PCR and normalized to that of GAPDH. Results are presented as the mean $\pm \operatorname{SEM}(n=9)(* p<0.05, * * p<0.01$, N.S.: Not significant $)$. 
Effect of OLE on serum biochemical and cytokines in HFDfed mice. In serum biochemical and cytokine analysis, the levels of TG, FFA, and glucose were significantly ameliorated in both the OLE and garcinia groups compared to those in the HFD group (Figure 3A). Furthermore, the OLE group showed significantly ameliorated TC serum levels, while administration of OLE or garcinia had no significant effect on the serum levels of HDL and low-density lipoprotein $(\mathrm{LDV})+$ very low-density lipoprotein (VLDL). Additionally, OLE administration resulted in significantly lower concentrations of leptin at 12 weeks and both the OLE and garcinia groups showed significantly upregulated adiponectin levels from 8 to 12 weeks (Figure 3B).

Effect of OLE on adipogenesis and thermogenesis gene expression in adipose tissue. Expression analysis of genes related to adipogenesis and thermogenesis in the epididymal fat of the OLE and garcinia groups showed that the mRNA expression levels of PPAR- $\gamma$ and C/EBP $\alpha$ were significantly downregulated compared to those in the HFD group. OLE treatment significantly upregulated PGC- $1 \alpha$ and UPC-1 mRNA levels (Figure 4).

\section{Discussion}

This study was conducted to investigate whether OLE has anti-obesity effects in high-fat diet-induced mice. The results indicated that OLE prevented obesity by downregulating adipogenesis and up-regulating thermogenesis in adipose tissue.

The incidence of obesity has increased because of the lack of exercise and poor eating habits of people; therefore, methods for managing obesity have gained attention (24). Additionally, studies have focused on the development of therapeutic agents from natural products that have few side effects. Olive leaf is a natural substance with therapeutic properties, and its extract contains several bioactive compounds including oleuropein, luteolin, hydroxytyrosol, apigenin, caffeic acid, and rutin (25). Recent studies demonstrated that olive leaf constituents improve management of obesity by decreasing the accumulation of intracellular lipid in the 3T3-L1 pre-adipocyte cell line (26-32). According to the results of these studies, OLE compound has anti-obesity effects. The present study showed that cumulative weight gain and FER were significantly decreased in HFD-fed mice after OLE treatment (Figure 1). Furthermore, the total visceral fatty weight was reduced by OLE administration (Figure 2).

Adipocytes in fat tissue secrete numerous hormones and cytokines to regulate lipid, glucose, and energy metabolism, thus maintaining the energy balance (33). However, adipocyte accumulation in adipose tissue may cause obesity and related complications. Recent studies demonstrated that long-term HFD increases in serum TG, FFA, glucose, TC, HDL, and
LDL decrease cholesterol levels, leading to an imbalance in serum lipid composition $(24,34,35)$. This imbalance is considered as the main risk factor for several diseases. OLE effectively decreased TG, FFA, glucose, and TC levels in the serum, while HDL and LDL-cholesterol levels were not significantly changed compared to those in the HDF group. Leptin and adiponectin are secreted mainly from adipose tissue to control energy homeostasis (36). Leptin in the plasma and adipose tissue are related to energy stores; leptin levels are increased in obesity (37) and the serum levels of leptin are proportional to fat mass in various obesity rodent models (3, 38). Additionally, adiponectin exerts potent effects on the nervous system to regulate energy expenditure $(37,39,40)$. Serum levels of adiponectin decrease with obesity and are positively associated with insulin sensitivity; a previous study showed that weight loss elevates plasma adiponectin levels $(41,42)$. In this study, we found that leptin levels were significantly reduced in the OLE group, while the opposite results were observed for adiponectin.

Adipogenesis is the process of a pre-adipocyte becoming a mature adipocyte; both $\operatorname{PPAR} \gamma$ and $\mathrm{C} / \mathrm{EBP} \alpha$ are key transcription factors involved in adipocyte differentiation (7, 43-45). Recent studies evaluated thermogenesis in obesity mouse models by measuring PGC- $1 \alpha$ and UPC- 1 levels (4648). The present study confirmed that OLE treatment significantly inhibited the expression of PPAR $\gamma$ and $\mathrm{C} / \mathrm{EBP} \alpha$ and significantly elevated PGC- $1 \alpha$ and UPC- 1 levels. Taken together, these results suggest that the anti-obesity effects of OLE occur through the control of adipogenesis and thermogenesis in vesical adipose tissue. Recently, hepatic lipid metabolism was shown to influence obesity and may be a therapeutic target (49). Therefore, further studies are needed to evaluate the effects of OLE on liver metabolism and predict the efficacy of OLE in obesity patients.

\section{Conclusion}

In conclusion, OLE significantly ameliorated increases in body weight, visceral fat, and serum lipid levels in HFD-diet mice. Furthermore, OLE showed anti-obesity effects by regulating the expression of molecules involved in adipogenesis and thermogenesis in the adipose tissue. Taken together, our results suggest that OLE is useful for preventing or treating obesity.

\section{Conflicts of Interest}

There are no conflicts of interest to declare regarding this study.

\section{Authors' Contributions}

YCJ, HWK: conception and design, collection and/or assembly of data, data analysis and interpretation; BKM, JYC, HJS, JYL, JYK, 
SBW: collection and/or assembly of data; QL, HWL: conception and design, data analysis and interpretation, manuscript writing, final approval of manuscript.

\section{Acknowledgements}

This research was supported by the MOTIE (Ministry of Trade, Industry and Energy), Republic of Korea, under the Support Project And R\&D Company (SPARC) (Grant No. N0002416) supervised by the KIAT (Korea Institute for Advancement of Technology).

\section{References}

1 Lowell BB and Spiegelman BM: Towards a molecular understanding of adaptive thermogenesis. Nature 404(6778): 652, 2000. PMID: 10766252. DOI: $10.1038 / 35007527$

2 Luppino FS, de Wit LM, Bouvy PF, Stijnen T, Cuijpers P, Penninx BW and Zitman FG: Overweight, obesity, and depression: A systematic review and meta-analysis of longitudinal studies. Arch Gen Psychiatry 67(3): 220-229, 2010. PMID: 20194822. DOI: 10.1001/archgenpsychiatry.2010.2

3 Fang $\mathrm{P}$, He B, Yu M, Shi M, Zhu Y, Zhang Z and Bo P: Treatment with celastrol protects against obesity through suppression of galanin-induced fat intake and activation of pgc$1 \alpha /$ glut 4 axis-mediated glucose consumption. Biochim Biophys Acta Mol Basis Dis, 2019. PMID: 30742994. DOI: 10.1016/ j.bbadis.2019.02.002

4 Cazzaniga $\mathrm{M}$ and Bonanni B: Relationship between metabolic disorders and breast cancer incidence and outcomes. Is there a preventive and therapeutic role for berberine? Anticancer Res 38(8): 4393-4402, 2018. PMID: 30061203. DOI: 10.21873/ anticanres.12741

5 Prestwich TC and MacDougald OA: Wnt/ $\beta$-catenin signaling in adipogenesis and metabolism. C urr Opin Cell Biol 19(6): 612617, 2007. PMID: 17997088. DOI: 10.1016/j.ceb.2007.09.014

6 Tontonoz P, Hu E and Spiegelman BM: Stimulation of adipogenesis in fibroblasts by ppar 2 , a lipid-activated transcription factor. Cell 79(7): 1147-1156, 1994. PMID: 8001151.

7 Siersbæk R, Nielsen R and Mandrup S: Transcriptional networks and chromatin remodeling controlling adipogenesis. Trends Endocrin Met 23(2): 56-64, 2012. PMID: 22079269. DOI: 10.1016/j.tem.2011.10.001

8 Lin F-T and Lane MD: Ccaat/enhancer binding protein alpha is sufficient to initiate the 3t3-11 adipocyte differentiation program. P Natl Acad Sci 91(19): 8757-8761, 1994. PMID 8090719.

9 Zanotti S, Stadmeyer L, Smerdel-Ramoya A, Durant D and Canalis E: Misexpression of ccaat/enhancer binding protein beta causes osteopenia. J Endocrinol 201(2): 263-274, 2009. PMID: 19218285. DOI: $10.1677 /$ JOE-08-0514

10 Virtanen KA, Lidell ME, Orava J, Heglind M, Westergren R, Niemi T, Taittonen M, Laine J, Savisto N-J and Enerbäck S: Functional brown adipose tissue in healthy adults. New Engl $\mathrm{J}$ Med 360(15): 1518-1525, 2009. PMID: 19357407. DOI: 10.1056/NEJMoa0808949

11 van Marken Lichtenbelt WD, Vanhommerig JW, Smulders NM, Drossaerts JM, Kemerink GJ, Bouvy ND, Schrauwen P and Teule GJ: Cold-activated brown adipose tissue in healthy men. New Engl J Med 360(15): 1500-1508, 2009. PMID: 19357405. DOI: $10.1056 /$ NEJMoa0808718
$12 \mathrm{Wu}$ J, Boström P, Sparks LM, Ye L, Choi JH, Giang A-H, Khandekar M, Virtanen KA, Nuutila P and Schaart G: Beige adipocytes are a distinct type of thermogenic fat cell in mouse and human. Cell 150(2): 366-376, 2012. PMID: 22796012. DOI: $10.1016 /$ j.cell.2012.05.016

13 Cypess AM, Lehman S, Williams G, Tal I, Rodman D, Goldfine AB, Kuo FC, Palmer EL, Tseng YH and Doria A: Identification and importance of brown adipose tissue in adult humans. New Engl J Med 360(15): 1509-1517, 2009. PMID: 19357406. DOI: 10.1056/NEJMoa0810780

14 Shabalina IG, Petrovic N, de Jong JM, Kalinovich AV, Cannon $\mathrm{B}$ and Nedergaard $\mathrm{J}$ : Ucp1 in brite/beige adipose tissue mitochondria is functionally thermogenic. Cell Rep 5(5): 11961203, 2013. PMID: 24290753. DOI: 10.1016/j.celrep. 2013.10.044

15 Kong X, Banks A, Liu T, Kazak L, Rao RR, Cohen P, Wang X, $\mathrm{Yu}$ S, Lo JC and Tseng YH: Irf4 is a key thermogenic transcriptional partner of pgc-1 $\alpha$. Cell 158(1): 69-83, 2014. PMID: 24995979. DOI: 10.1016/j.cell.2014.04.049

16 Seale P, Conroe HM, Estall J, Kajimura S, Frontini A, Ishibashi J, Cohen P, Cinti S and Spiegelman BM: Prdm16 determines the thermogenic program of subcutaneous white adipose tissue in mice. J Clin Invest 121(1): 96-105, 2011. PMID: 21123942. DOI: $10.1172 / \mathrm{JCI} 44271$

17 Cohen P, Levy JD, Zhang Y, Frontini A, Kolodin DP, Svensson KJ, Lo JC, Zeng X, Ye L and Khandekar MJ: Ablation of prdm 16 and beige adipose causes metabolic dysfunction and a subcutaneous to visceral fat switch. Cell 156(1-2): 304-316, 2014. PMID: 24439384. DOI: 10.1016/j.cell.2013.12.021

18 Khayyal MT, El-Ghazaly MA, Abdallah DM, Nassar NN, Okpanyi SN and Kreuter M-H: Blood pressure lowering effect of an olive leaf extract (Olea europaea) in L-NAME induced hypertension in rats. Arzneimittelforsch 52(11): 797-802, 2002. PMID: 12489249. DOI: 10.1055/s-0031-1299970

19 Wang L, Geng C, Jiang L, Gong D, Liu D, Yoshimura H and Zhong L: The anti-atherosclerotic effect of olive leaf extract is related to suppressed inflammatory response in rabbits with experimental atherosclerosis. Eur J Nutr 47(5): 235-243, 2008. PMID: 18654736. DOI: 10.1007/s00394-008-0717-8

20 Abaza L, Talorete TP, Yamada P, Kurita Y, Zarrouk M and Isoda $\mathrm{H}$ : Induction of growth inhibition and differentiation of human leukemia hl-60 cells by a tunisian gerboui olive leaf extract. Biosci Biotech Bioch: 0704090373-0704090373, 2007. PMID: 17485840. DOI: $10.1271 / \mathrm{bbb} .60716$

21 Eidi A, Eidi M and Darzi R: Antidiabetic effect of Olea europaea 1. in normal and diabetic rats. Phytother Res 23(3): 347-350, 2009. PMID: 18844257. DOI: $10.1002 /$ ptr.2629

22 Poudyal H, Campbell $\mathrm{F}$ and Brown L: Olive leaf extract attenuates cardiac, hepatic, and metabolic changes in high carbohydrate-, high fat-fed rats. J Nutr 140(5): 946-953, 2010. PMID: 20335636. DOI: 10.3945/jn.109.117812

23 Perrinjaquet-Moccetti T, Busjahn A, Schmidlin C, Schmidt A, Bradl B and Aydogan C: Food supplementation with an olive (Olea europaea 1.) leaf extract reduces blood pressure in borderline hypertensive monozygotic twins. Phytother Res 22(9): 1239-1242, 2008. PMID: 18729245. DOI: 10.1002/ptr.2455

24 Cho Y-R, Lee JA, Kim YY, Kang J-S, Lee J-H and Ahn E-K: Anti-obesity effects of clausena excavata in high-fat diet-induced obese mice. Biomed Pharmacother 99: 253-260, 2018. PMID: 29334669. DOI: $10.1016 /$ j.biopha.2018.01.069 
25 Shen Y, Song SJ, Keum N and Park T: Olive leaf extract attenuates obesity in high-fat diet-fed mice by modulating the expression of molecules involved in adipogenesis and thermogenesis. Evid-Based Compl Alternal Med 2014: 971890, 2014. PMID: 24624222. DOI: 10.1155/2014/971890

26 Drira R, Chen S and Sakamoto K: Oleuropein and hydroxytyrosol inhibit adipocyte differentiation in 3t3-11 cells. Life Sci 89(19-20): 708-716, 2011. PMID: 21945192. DOI: 10.1016/j.lfs.2011.08.012

27 Ono $M$ and Fujimori K: Antiadipogenic effect of dietary apigenin through activation of ampk in 3t3-11 cells. J Agr Food Chem 59(24): 13346-13352, 2011. PMID: 22098587. DOI: 10.1021/jf203490a

28 Park HS, Kim SH, Kim YS, Ryu SY, Hwang JT, Yang HJ, Kim GH, Kwon DY and Kim MS: Luteolin inhibits adipogenic differentiation by regulating ppary activation. Biofactors 35(4): 373-379, 2009. PMID: 19353690. DOI: 10.1002/biof.38

29 Cho AS, Jeon SM, Kim MJ, Yeo J, Seo KI, Choi MS and Lee MK: Chlorogenic acid exhibits anti-obesity property and improves lipid metabolism in high-fat diet-induced-obese mice. Food Chem Toxicol 48(3): 937-943, 2010. PMID: 20064576 DOI: $10.1016 /$ j.fct.2010.01.003

30 Hao J, Shen W, Yu G, Jia H, Li X, Feng Z, Wang Y, Weber P, Wertz $\mathrm{K}$ and Sharman E: Hydroxytyrosol promotes mitochondrial biogenesis and mitochondrial function in $3 \mathrm{t} 3-11$ adipocytes. J Nutr Biochem 21(7): 634-644, 2010. PMID: 19576748. DOI: 10.1016/j.jnutbio.2009.03.012

31 Myoung HJ, Kim G and Nam KW: Apigenin isolated from the seeds of perilla frutescens britton var crispa (benth.) inhibits food intake in c57bl/6j mice. Arch Pharm Res 33(11): 1741-1746, 2010. PMID: 21116776. DOI: $10.1007 / \mathrm{s} 12272-010-1105-5$

32 Hsu CL, Wu CH, Huang SL and Yen GC: Phenolic compounds rutin and o-coumaric acid ameliorate obesity induced by highfat diet in rats. J Agric Food Chem 57(2): 425-431, 2009. PMID: 19119847. DOI: $10.1021 /$ jf $802715 t$

33 Satoh N, Naruse M, Usui T, Tagami T, Suganami T, Yamada K, Kuzuya H, Shimatsu A and Ogawa Y: Leptin-to-adiponectin ratio as a potential atherogenic index in obese type 2 diabetic patients. Diabetes Care 27(10): 2488-2490, 2004. PMID: 15451921.

34 Sung YY, Yoon T, Yang WK, Moon BC and Kim HK: Antiobesity effects of actinidia polygama extract in mice with highfat diet-induced obesity. Mol med Rep 7(2): 396-400, 2013. PMID: 23255063. DOI: 10.3892/mmr.2012.1239

35 Chuah LO, Ho WY, Beh BK and Yeap SK: Updates on antiobesity effect of garcinia origin (-)-hca. Evid Based Complement Alternat Med 2013: 751658, 2013. PMID: 23990846. DOI: $10.1155 / 2013 / 751658$

36 Stern JH, Rutkowski JM and Scherer PE: Adiponectin, leptin, and fatty acids in the maintenance of metabolic homeostasis through adipose tissue crosstalk. Cell Metab 23(5): 770-784, 2016. PMID: 27166942. DOI: 10.1016/j.cmet.2016.04.011

37 Yadav A, Kataria MA, Saini V and Yadav A: Role of leptin and adiponectin in insulin resistance. Clin Chim Acta 417: 80-84, 2013. PMID: 23266767. DOI: 10.1016/j.cca.2012.12.007

38 Myers MG, Cowley MA and Münzberg H: Mechanisms of leptin action and leptin resistance. Annu Rev Physiol 70: 537-556, 2008. PMID: 17937601. DOI: 10.1146/annurev.physiol. 70.113006.100707

39 Park S, Kim D, Kwon D and Yang H: Long-term central infusion of adiponectin improves energy and glucose homeostasis by decreasing fat storage and suppressing hepatic gluconeogenesis without changing food intake. J Neuroendocrinol 23(8): 687-698, 2011. PMID: 21599766. DOI: 10.1111/j.1365-2826.2011.02165.x

40 Qi Y, Takahashi N, Hileman SM, Patel HR, Berg AH, Pajvani UB, Scherer PE and Ahima RS: Adiponectin acts in the brain to decrease body weight. Nat Med 10(5): 524, 2004. PMID: 15077108. DOI: $10.1038 / \mathrm{nm} 1029$

41 Arita Y, Kihara S, Ouchi N, Takahashi M, Maeda K, Miyagawa J-i, Hotta K, Shimomura I, Nakamura T and Miyaoka K: Paradoxical decrease of an adipose-specific protein, adiponectin, in obesity. Biochem Biophys Res Commun 257(1): 79-83, 1999. PMID: 10092513.

42 Hotta K, Funahashi T, Arita Y, Takahashi M, Matsuda M, Okamoto Y, Iwahashi H, Kuriyama H, Ouchi N and Maeda K: Plasma concentrations of a novel, adipose-specific protein, adiponectin, in type 2 diabetic patients. Arterioscler Thromb Vasc Biol 20(6): 1595-1599, 2000. PMID: 10845877.

43 Olofsson LE, Orho-Melander M, William-Olsson L, Sjoholm K, Sjostrom L, Groop L, Carlsson B, Carlsson LM and Olsson B: Ccaat/enhancer binding protein $\alpha(\mathrm{c} / \mathrm{ebp} \alpha)$ in adipose tissue regulates genes in lipid and glucose metabolism and a genetic variation in c/ebpa is associated with serum levels of triglycerides. J Clin Endocrinol Metab 93(12): 4880-4886, 2008. PMID: 18765514. DOI: 10.1210/jc.2008-0574

44 Hadrich F, Mahmoudi A, Bouallagui Z, Feki I, Isoda H, Feve B and Sayadi S: Evaluation of hypocholesterolemic effect of oleuropein in cholesterol-fed rats. Chem Biol Interact 252: 5460, 2016. PMID: 27019295. DOI: 10.1016/j.cbi.2016.03.026

45 Matsubara T, Takakura N, Urata M, Muramatsu Y, Tsuboi M, Yasuda K, Addison WN, Zhang M, Matsuo K and Nakatomi C: Geranylgeraniol induces ppar $\gamma$ expression and enhances the biological effects of a ppar $\gamma$ agonist in adipocyte lineage cells. In Vivo 32(6): 1339-1344, 2018. PMID: 30348686. DOI: 10.21873/invivo.11384

46 Kim HL, Park J, Jung Y, Ahn KS and Um JY: Platycodin d, a novel activator of amp-activated protein kinase, attenuates obesity in $\mathrm{db} / \mathrm{db}$ mice via regulation of adipogenesis and thermogenesis. Phytomedicine 52: 254-263, 2019. PMID: 30599906. DOI: 10.1016/j.phymed.2018.09.227

47 Fournier B, Murray B, Gutzwiller S, Marcaletti S, Marcellin D, Bergling S, Brachat S, Persohn E, Pierrel E and Bombard F: Blockade of the activin receptor iib activates functional brown adipogenesis and thermogenesis by inducing mitochondrial oxidative metabolism. Mol Cell biology 32(14): 2871-2879, 2012.

48 Feldmann HM, Golozoubova V, Cannon B and Nedergaard J: Ucp 1 ablation induces obesity and abolishes diet-induced thermogenesis in mice exempt from thermal stress by living at thermoneutrality. Cell Metab 9(2): 203-209, 2009. PMID: 19187776. DOI: 10.1016/j.cmet.2008.12.014

49 Hong SJ, Lee JH, Kim EJ, Yang HJ, Park JS and Hong SK: Anti-obesity and anti-diabetic effect of neoagarooligosaccharides on high-fat diet-induced obesity in mice. Mar Drugs 15(4): 90, 2017. PMID: 28333098. DOI: 10.3390/md15040090

Received February 22, 2019

Revised March 26, 2019

Accepted March 27, 2019 